\title{
Dihydroaeruginoic acid synthetase and pyochelin synthetase, products of the pchEF genes, are induced by extracellular pyochelin in Pseudomonas aeruginosa
}

\author{
Cornelia Reimmann, Laura Serino, † Markus Beyelerł and Dieter Haas
}

Author for correspondence: Dieter Haas. Tel: +4121692 56 31. Fax: +41216925635. e-mail: Dieter.Haas@lbm.unil.ch

Laboratoire de Biologie Microbienne, Université de Lausanne, $\mathrm{CH}-1015$ Lausanne, Switzerland

\begin{abstract}
The siderophore pyochelin of Pseudomonas aeruginosa is derived from one molecule of salicylate and two molecules of cysteine. Two cotranscribed genes, pchEF, encoding peptide synthetases have been identified and characterized. pchE was required for the conversion of salicylate to dihydroaeruginoate (Dha), the condensation product of salicylate and one cysteine residue and pchF was essential for the synthesis of pyochelin from Dha. The deduced PchE (156 kDa) and PchF (197 kDa) proteins had adenylation, thiolation and condensation/cyclization motifs arranged as modules which are typical of those peptide synthetases forming thiazoline rings. The pchEF genes were coregulated with the pchDCBA operon, which provides enzymes for the synthesis (PchBA) and activation (PchD) of salicylate as well as a putative thioesterase (PchC). Expression of a translational pchE'-'lacz fusion was strictly dependent on the PchR regulator and was induced by extracellular pyochelin, the end product of the pathway. Iron replete conditions led to Fur (ferric

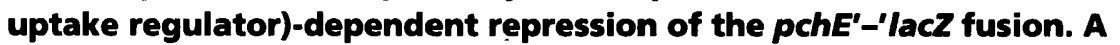
translational pchD'-'lacZ fusion was also positively regulated by PchR and pyochelin and repressed by Fur and iron. Thus, autoinduction by pyochelin (or ferric pyochelin) and repression by iron ensure a sensitive control of the pyochelin pathway in $P$. aeruginosa.
\end{abstract}

Keywords: Pseudomonas aeruginosa, siderophore, pyochelin, non-ribosomal peptide synthesis, autoinduction

\section{INTRODUCTION}

Under iron-limiting growth conditions, Pseudomonas aeruginosa produces two major siderophores, pyoverdin (Meyer \& Abdallah, 1978; Cox \& Adams, 1985) and pyochelin (Cox, 1980; Rinehart et al., 1995). The hydroxamate siderophore pyoverdin has a greater affinity for $\mathrm{Fe}(\mathrm{III})$ than has pyochelin (Cox \& Graham, 1979). Siderophore-mediated iron uptake requires the outer-membrane receptors FpvA (Poole et al., 1993) and

\footnotetext{
†Present address: University of Bristol, Department of Pathology and Microbiology, Bristol BS8 ITD, UK.

‡Present address: Emmenegger AG, CH-4416 Bubendorf, Switzerland. Abbreviations: CTAB, cetyltrimethylammonium bromide; Dha, dihydroaeruginoic acid (dihydroaeruginoate).

The GenBank accession number for the sequence reported in this paper is AF074705.
}

FptA (Ankenbauer \& Quan, 1994) which recognize $\mathrm{Fe}(\mathrm{III})$ pyoverdin and $\mathrm{Fe}(\mathrm{III})$ pyochelin complexes, respectively. Salicylate, the metabolic precursor of pyochelin (Ankenbauer \& Cox, 1988), is a strong iron chelator in the absence of inorganic phosphate (Martell \& Smith, 1977; Ratledge et al., 1974) and can also promote iron uptake in $P$. aeruginosa (Meyer, 1992). It is not known whether a receptor protein is involved in salicylate-mediated iron uptake. Pyoverdin and pyochelin both contribute to the virulence of the opportunistic pathogen $P$. aeruginosa (Meyer et al., 1996; Cox, 1982). In particular, pyochelin enhances hydroxyl radical formation and epithelial injury when $\mathrm{Fe}$ (III) and pyocyanin are present (Britigan et al., 1997).

Excess iron represses the biosynthesis of pyoverdin, salicylate and pyochelin (Cox \& Graham, 1979; Cox \& Adams, 1985; Visca et al., 1993). Repression occurs via the Fur (ferric uptake regulator) protein, which, in the 
presence of iron, binds to the promoters of $p v d S$ and pchR (Leoni et al., 1996; Ochsner et al., 1995). The PvdS and PchR proteins positively regulate the biosynthesis of pyoverdin and pyochelin, respectively. PvdS belongs to a class of alternative sigma factors (Miyazaki et al., 1995; Cunliffe et al., 1995), whereas PchR is an AraC-like regulatory protein (Heinrichs \& Poole, 1993). In the presence of pyochelin, PchR activates the expression of fpt $A$ and $p c h R$, whereas in the absence of pyochelin, PchR appears to act as a repressor of the receptor gene and of its own gene (Heinrichs \& Poole, 1996).

The biosynthesis of pyochelin requires the Fur-regulated $p c h D C B A$ operon, which lies next to the divergently transcribed $p c h R$ gene in $P$. aeruginosa (Serino et al., 1997). The PchA and PchB enzymes convert chorismate to salicylate via isochorismate (Serino et al., 1995; C. Gaille, C. Reimmann \& D. Haas, unpublished data). The deduced PchD protein resembles adenylate-forming enzymes and probably activates salicylate at the carboxyl group. The PchC protein shows homology to thioesterases (Serino et al., 1997). Expression of the pchDCBA operon of $P$. aeruginosa is also necessary for the formation of the antibiotic and iron-chelator dihydroaeruginoic acid (dihydroaeruginoate; Dha) (Serino et al., 1997). Dha is the condensation product of salicylate and cyclized D-cysteine (Carmi et al., 1994). Formally, pyochelin could be derived from Dha by condensation (amide bond formation), cyclization, reduction and methylation of a second cysteine residue (Rinehart et al., 1995; Serino et al., 1997). Thus, Dha would be the precursor of pyochelin in a linear pathway. However, considering the available evidence, the alternative possibility exists that Dha might be the product of a branch of the salicylate-pyochelin pathway (Serino $e t$ al., 1997).

Here we describe two new genes, $p c h E$ and $p c h F$, which encode peptide synthetases involved in the sequential formation of Dha and pyochelin in P. aeruginosa and we show that the expression of these genes depends on the presence of extracellular pyochelin. A model is presented in which each step of a linear salicylate-Dha-pyochelin pathway is assigned to specific functions of the $p c h D C B A$ and $p c h E F$ gene products.

\section{METHODS}

Bacterial strains and growth conditions. Bacterial strains used in this study are listed in Table 1. Bacteria were usually grown on nutrient agar and in nutrient yeast broth (Stanisich \& Holloway, 1972) at $37^{\circ} \mathrm{C}$ (Escherichia coli and Pseudomonas aeruginosa) or at $30^{\circ} \mathrm{C}$ (Pseudomonas fluorescens). Iron-depleted Casamino acids medium (DCAA medium; Visca et al., 1993) was used to study the regulation of the $p c h E$ gene by iron. Salicylate, Dha and pyochelin were quantified in culture supernatants of $P$. aeruginosa and $P$. fluorescens strains grown in GGP medium containing glycerol and proteosepeptone (Carmi et al., 1994), in which limited iron availability results in the production of large amounts of Dha and pyochelin. Antibiotics, when required, were added to the growth media at the following concentrations: tetracycline, $25 \mu \mathrm{g} \mathrm{ml}^{-1}$ for E. coli and $P$. fluorescens and $100 \mu \mathrm{g} \mathrm{ml}^{-1}$ for $P$. aeruginosa ; ampicillin, $100 \mu \mathrm{g} \mathrm{ml}^{-1}$ for E. coli ; carbenicillin,
$250 \mu \mathrm{g} \mathrm{ml}^{-1}$ for $P$. aeruginosa; spectinomycin, $50 \mu \mathrm{g} \mathrm{ml}^{-1}$ for $E$. coli and $1000 \mu \mathrm{g} \mathrm{m}^{-1}$ for $P$. aeruginosa. To counterselect $E$. coli donor cells in matings with $P$. aeruginosa or $P$. fluorescens, chloramphenicol was used at $10 \mu \mathrm{g} \mathrm{ml}^{-1}$.

Construction of plasmids and gene replacement mutants. All plasmids used in this study are described in Table 1. To construct plasmid pME3384, a BamHI (restriction site underlined) DNA linker (GGATCCGGTGATTGATTGAGCAAGCTTGCTCAATCAATCACCGGATCC) termed $\omega$ and carrying translation stops (bold type) in all three reading frames and in both orientations, was inserted at the $B g l$ II site of $p c h R$. To construct mutations in the chromosomal $p c h$ genes of $P$. aeruginosa, derivatives of the suicide plasmids pME3087 and pME3088 (Voisard et al., 1994) were mobilized from E. coli S17-1 to strain PAO1 and chromosomally integrated with selection for tetracycline resistance. Excision of the vector via a second crossing over was obtained by enrichment for tetracycline-sensitive cells (Ye et al., 1995). All gene replacement mutants were checked by Southern blot analysis (data not shown).

DNA manipulation and sequencing. Standard DNA manipulations were carried out as described by Sambrook et al. (1989). Small-scale preparations of plasmid DNA were obtained by the cetyltrimethylammonium bromide (CTAB) method (Del Sal et al., 1988) and large-scale preparations were performed using Qiagen-tip 100 columns. Chromosomal DNA was prepared according to Gamper et al. (1992). Restriction and DNA modifying enzymes were used following the instructions of the manufacturers. DNA fragments were purified from agarose gels with a Geneclean DNA extraction kit (Bio 101). Transformation of E. coli and P. aeruginosa was done by the standard $\mathrm{CaCl}_{2}$ procedure (Sambrook et al., 1989) or by electroporation (Farinha \& Kropinski, 1990). The complete nucleotide sequence of $p c h E$ and $p c h F$ was determined on both strands by a joint effort of Euro Sequence Gene Service (ESGS; Evry, France), Genome Express SA (Grenoble, France) and this laboratory, except for a $2.4 \mathrm{~kb}$ EcoRI fragment in $p c h E$ (Fig. 1) which was sequenced on only one strand and compared to the DNA sequence already available from the $P$. aeruginosa genome sequencing project (http://www.pseudomonas.com). Nucleotide sequences were analysed with the programs FASTA, GAP, BESTFIT, MOTIFS, ISOELECTRIC, PEPTIDESORT and CODONPREFERENCE using the Genetics Computer group (GCG) package.

Protein expression. $p c h E$ and $p c h F$ were cloned under the control of the T7 promoter in pALTER-Ex2 (Fig. 2). In nutrient yeast broth cultures of E. coli JM109(DE3) harbouring these constructs, the chromosomal T7 RNA polymerase was induced at a cell density of $\mathrm{OD}_{600}=0.5$ for $2 \mathrm{~h}$ by the addition of $1 \mathrm{mM}$ IPTG. Rifampicin was then added at $200 \mu \mathrm{g} \mathrm{ml}^{-1}$. Cells were harvested $2 \mathrm{~h}$ later and proteins were analysed on a $7.5 \%(w / v)$ SDS-polyacrylamide gel as described previously (Serino et al., 1995).

Identification of salicylate, Dha and pyochelin in culture supernatants of $\boldsymbol{P}$. aeruginosa and $\boldsymbol{P}$. fluorescens. Bacterial strains were grown in GGP medium to stationary phase $\left(\mathrm{OD}_{600} \approx 7-11\right.$, measured in a Pharmacia Ultrospec III spectrophotometer). For HPLC analysis, ethyl acetate extracts of culture supernatants acidified to $\mathrm{pH} \mathrm{1-2}$ were dried by evaporation and dissolved in $200 \mu \mathrm{l} 60 \%(\mathrm{v} / \mathrm{v})$ methanol and $10 \mathrm{mM} \mathrm{H}_{3} \mathrm{PO}_{4}$. An aliquot of $100 \mu \mathrm{l}$ was injected into an HPLC system (Serino et al., 1995). A binary gradient consisting of solvent $\mathrm{A}\left(10 \mathrm{mM} \mathrm{H}_{3} \mathrm{PO}_{4}\right)$ and solvent $\mathrm{B}(95 \%$ methanol in $10 \mathrm{mM} \mathrm{H}_{3} \mathrm{PO}_{4}$ ) was used as follows: 0-29 min with $20-83 \%$ solvent $\mathrm{B}$ and 2 min with $83-100 \%$ solvent $\mathrm{B}$. Elution was carried out at room temperature with a flow rate of $0.8 \mathrm{ml}$ 


\begin{tabular}{|c|c|c|}
\hline Strain/plasmid & Relevant characteristics/genotype & Source/reference \\
\hline \multicolumn{3}{|l|}{ E. coli } \\
\hline $\mathrm{DH} 5 \alpha$ & $\begin{array}{l}\text { recA1 end } A 1 \text { hsdR17 deoR thi-1 supE44 gyrA96 relA1 } \Delta(\text { lacZYA-argF) U169 } \\
(\phi 80 \mathrm{~d} l a c Z \Delta \mathrm{M} 15)\end{array}$ & Sambrook et al. (1989) \\
\hline JM109(DE3) & Chromosomal T7 polymerase & Promega \\
\hline S17-1 & thi pro hsdR recA; chromosomal RP4 $\left(\mathrm{Tra}^{+} \mathrm{Tc}^{\mathrm{s}} \mathrm{Km}^{\mathrm{s}} \mathrm{Ap}^{\mathrm{s}}\right)$ & Simon et al. (1983) \\
\hline \multicolumn{3}{|c|}{ 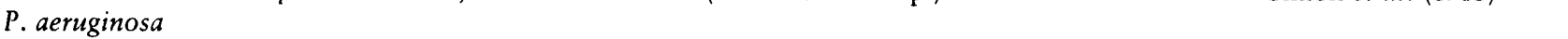 } \\
\hline PAO1 & Wild type & ATCC 15692 \\
\hline PAO1A4 & fur-4 & Barton et al. (1996) \\
\hline PAO6274 & $p c h R:: \omega$ (insertion of a 42 bp linker in the BglII site of $p c h R$ ) & This work (Fig. 1) \\
\hline PAO6295 & $p c h F:: \Omega \mathrm{Sm} / \mathrm{Sp}$ & This work (Fig. 1) \\
\hline PAO6296 & Chromosomal insertion of $\Omega \mathrm{Sm} / \mathrm{Sp}$ at the $B a m \mathrm{HI}$ site downstream of $p c h F$ & This work (Fig. 1) \\
\hline PAO6297 & Chromosomal deletion of a $1 \mathrm{~kb}$ EcoRV-PvuII fragment in $p c b B A$ & This work \\
\hline PAO6310 & Chromosomal deletion of a $2.4 \mathrm{~kb} E c o \mathrm{RI}$ fragment in $p c h E(=p c h E \Delta E c o \mathrm{RI})$ & This work (Fig. 1) \\
\hline PAO6312 & $p c h E \Delta E c o \mathrm{RI}:: \Omega \mathrm{Sm} / \mathrm{Sp}$ & This work (Fig. 1) \\
\hline PAO6323 & Chromosomal deletion of two $S p h \mathrm{I}$ fragments $(0.55$ and $2.4 \mathrm{~kb})$ in $p c h F$ & This work (Fig. 1) \\
\hline PALS128-17 & $p v d B p c h B$ or $p c h A$ & Serino et al. (1995) \\
\hline \multicolumn{3}{|l|}{ P. fluorescens } \\
\hline P3 & Wild type, naturally deficient in salicylate, Dha and pyochelin production & Voisard et al. (1989) \\
\hline \multicolumn{3}{|c|}{ 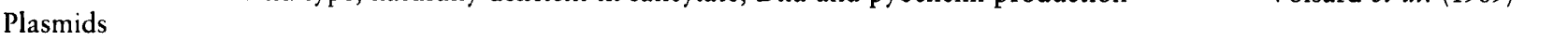 } \\
\hline pALTER-Ex2 & $\mathrm{T} 7$ expression vector, $\mathrm{T} \mathrm{c}^{\mathrm{r}} ; \mathrm{p} 15 \mathrm{a}$ replicon & Promega \\
\hline $\mathrm{pHP} 45 \Omega$ & $\Omega \mathrm{Sm} / \mathrm{Sp}$ containing plasmid; $\mathrm{Ap} \mathrm{p}^{\mathrm{r}}, \mathrm{Sm} / \mathrm{Sp}^{\mathrm{r}}$ & Prentki \& Krisch (1984) \\
\hline pME3087 & $\begin{array}{l}\text { Suicide vector; Tcr ; ColE1 replicon; EcoRI KpnI BamHI XbaI PstI SphI HindIII } \\
\text { polylinker }\end{array}$ & Voisard et al. (1994) \\
\hline pME3088 & Suicide vector; $\mathrm{Tc}^{r}$; ColE1 replicon; EcoRI KpnI DraII XhoI HindIII polylinker & Voisard et al. (1994) \\
\hline pME3300 & $\begin{array}{l}\text { pLAFR } 3 \text { carrying the structural genes for salicylate, Dha and pyochelin } \\
\text { biosynthesis in PAO1 }\end{array}$ & $\begin{array}{l}\text { Serino et al. }(1995,1997) \\
\text { (Fig. 1) }\end{array}$ \\
\hline pME3302 & $\begin{array}{l}\text { Derivative of pME } 3300 \text { with a } 3.3 \mathrm{~kb} \text { Bam } \mathrm{HI} \text { deletion; carries the structural genes } \\
\text { for salicylate and Dha biosynthesis in PAO1 }\end{array}$ & This work (Fig. 1) \\
\hline pME3384 & $\begin{array}{l}\text { pME3087 carrying a } 1.8 \mathrm{~kb} \text { EcoRI-Sall fragment containing the } p c h R \text { gene } \\
\text { interrupted by a } 42 \text { bp linker }(\omega) \text { at the BglII site }\end{array}$ & This work \\
\hline pME6015 & $\mathrm{pVS} 1 / \mathrm{p} 15 \mathrm{~A}$ shuttle vector for construction of translational lacZ fusions; $\mathrm{Tc}^{\mathrm{r}}$ & $\begin{array}{l}\text { S. Heeb \& U. Schnider, } \\
\text { unpublished }\end{array}$ \\
\hline pME6122 & Translational $p c h D^{\prime}-{ }^{\prime} l a c Z$ fusion on pKT240 & Serino et al. (1997) \\
\hline pME6156 & $\begin{array}{l}\text { pME3088 carrying part of the } p c h D C B A \text { operon on a } 2.3 \mathrm{~kb} K p n \mathrm{I}-S a l \mathrm{I} \text { fragment, } \\
\text { but lacking a } 1 \mathrm{~kb} \text { internal EcoRV-PvuII fragment in } p c h B A\end{array}$ & This work \\
\hline pME6406 & $\begin{array}{l}\text { pME3088 carrying a } 5.8 \mathrm{~kb} E c o R I \text { fragment containing } 3.8 \mathrm{~kb} \text { of the chromosomal } \\
\text { region downstream of } p c h F \text { with a } 2 \mathrm{~kb} \Omega \mathrm{Sp} / \mathrm{Sm} \text { insertion at } B a m \mathrm{HI}\end{array}$ & This work \\
\hline pME6407 & $\begin{array}{l}\text { pME } 3088 \text { carrying a } 10.55 \mathrm{~kb} \text { EcoRI fragment containing } p c h F \text {, with a } 2 \mathrm{~kb} \\
\Omega S \mathrm{p} / \mathrm{Sm} \text { insertion at } B a m \mathrm{HI}\end{array}$ & This work \\
\hline pME6413 & pUCPKS carrying an $8.55 \mathrm{~kb} E c o \mathrm{RI}$ fragment containing $p c h F$ & This work (Fig. 1) \\
\hline pME6421 & $\begin{array}{l}\text { pME3088 carrying a } 5 \mathrm{~kb} \mathrm{BglII-ClaI} \text { fragment with } 5^{\prime} \text { and } 3^{\prime} \text { ends of } p c h E \text { but } \\
\text { lacking an internal EcoRI fragment of } 2 \cdot 4 \mathrm{~kb}\end{array}$ & This work \\
\hline pME6422 & $\begin{array}{l}\text { pME3088 carrying a } 7 \mathrm{~kb} \text { BglII-ClaI fragment with an internal EcoRI deletion in } \\
\text { pchE (see pME6421) and, in addition, an } \Omega \mathrm{Sp} / \mathrm{Sm} \text { cassette at the remaining } \\
\text { EcoRI site }\end{array}$ & This work \\
\hline pME6425 & $\begin{array}{l}\text { pME6015 carrying a } 0.5 \mathrm{~kb} P s t \text { f fragment containing the promoter region of } p c h E \\
\text { (translational } p c h E^{\prime}-{ }^{\prime} l a c Z \text { fusion) }\end{array}$ & This work \\
\hline pME6427 & $\begin{array}{l}\text { pME3088 carrying a } 5.6 \mathrm{~kb} \text { EcoRI fragment containing the } 5^{\prime} \text { and } 3^{\prime} \text { ends of } p c h F \\
\text { but lacking the internal } S p h \text { I fragments of } 0.55 \text { and } 2.4 \mathrm{~kb}\end{array}$ & This work (Fig. 1) \\
\hline pME6432 & pUCPSK carrying a $7 \cdot 4 \mathrm{~kb} S m a \mathrm{I}-K p n \mathrm{I}$ fragment containing $p c h F$ & This work (Fig. 1) \\
\hline pME6434 & pUCPSK carrying a $5.75 \mathrm{~kb} B g l \mathrm{II}-M u n \mathrm{I}$ fragment containing $p c h E$ & This work (Fig. 1) \\
\hline pME6436 & pUCPSK carrying a $12 \cdot 2 \mathrm{~kb} B g l \mathrm{lI}-E c o \mathrm{RI}$ fragment containing $p c h E$ and $p c h F$ & This work (Fig. 1) \\
\hline pME6438 & pUCPSK carrying an $11.3 \mathrm{~kb} B g l \mathrm{ll}-K p n \mathrm{l}$ fragment containing $p c h E$ and $p c h F$ & This work (Fig. 1) \\
\hline pME6441 & pME6443 derivative with an in-frame Pst I deletion of $2.4 \mathrm{~kb}$ in $p c h E$ & This work (Fig. 2) \\
\hline pME6442 & pME6441 derivative with an in-frame $S p h \mathrm{I}$ deletion of $2.95 \mathrm{~kb}$ in $p c h F$ & This work (Fig. 2) \\
\hline pME6443 & pALTER-Ex2 carrying $p c h E F$ on an $11.3 \mathrm{~kb} \mathrm{~N} c o$ I-EcoRI fragment & This work (Fig. 2) \\
\hline pUCPKS, SK & ColE1-pRO1600 shuttle vectors; $\mathrm{Ap}^{r}$ & Watson et al. (1996) \\
\hline
\end{tabular}

$\min ^{-1}$. Compounds were identified by their retention times and UV spectra. Salicylate and Dha were eluted at 21.7 and $23.2 \mathrm{~min}$, respectively. Pyochelin isomerizes spontaneously to a 3:1 mixture of pyochelin I and II (Rinehart et al., 1995). Pyochelin I and II were eluted at 27.6 and $29.7 \mathrm{~min}$, respectively. Dha, salicylate, pyochelin I and II were quantified 
at $256,237,258$ and $254 \mathrm{~nm}$, respectively. Salicylate was also quantified by fluorescence, using a detector set at $233 \mathrm{~nm}$ (excitation) and $422 \mathrm{~nm}$ (emission) with a $295 \mathrm{~nm}$ cut-off filter and a pulsed xenon lamp $(110 \mathrm{~Hz}, 2 \cdot 5 \mathrm{~W})$.

$(+)-(S)$-Dha was synthesized from D-cysteine and salicylonitrile as described previously (Serino et al., 1997). Pyochelin was isolated from a culture filtrate of strain PAO1(pME6413) grown in GGP medium and purified by HPLC. The identity of pyochelin was verified by ${ }^{1} \mathrm{H}-\mathrm{NMR}$ and by HPLC coupled with thermospray mass spectrometry and post-column addition of ammonium acetate as the ionizing agent.

\section{RESULTS}

\section{Identification of pchE and pchF as structural genes involved in the formation of Dha and pyochelin in $P$. aeruginosa}

The previously described salicylate- and pyochelinnegative mutant PALS128-17 of $P$. aeruginosa can be complemented with cosmid pME3300 (Fig. 1). This clone carries the $p c h D C B A$ operon lying next to the $p c h R$ gene, as well as the $f p t A$ receptor gene (Serino et al., 1995, 1997; Heinrichs \& Poole, 1993, 1996). To test if pME3300 carries additional genes required for the biosynthesis of Dha and pyochelin, we introduced the cosmid into $P$. fluorescens $\mathrm{P} 3$, a strain naturally deficient for salicylate, Dha and pyochelin formation. HPLC analysis revealed the presence of salicylate, Dha and pyochelin in culture supernatants of strain P3 carrying pME3300 (data not shown). When pME3302, a deletion derivative of pME3300 lacking an internal $3.3 \mathrm{~kb} \mathrm{BamHI}$ fragment between $p c h R$ and $f p t A$ (Fig. 1), was introduced into strain P3, salicylate and Dha were detectable in the supernatant, whereas pyochelin was absent (data not shown). These results indicate that cosmid pME3300 carries the genes needed for the formation of salicylate, Dha and pyochelin in $P$. fluorescens P3, whereas the genetic information present on pME3302 is sufficient for salicylate and Dha formation.

To identify and characterize the genes required for Dha and pyochelin formation, we subcloned a $11.2 \mathrm{~kb}$ $B g l I I-K p n I$ fragment of pME3300 into the vector pUCPKS, producing pME6438 (Fig. 1). This fragment, which contains the $3^{\prime}$ end of the $p c h R$ gene (Heinrichs \& Poole, 1993) and the downstream region, was sequenced. The $3^{\prime}$ end of the $p c h R$ gene is followed by two large ORFs designated $p c h E$ and $p c h F$ (Fig. 1). The $\mathrm{G}+\mathrm{C}$ contents of $p c h E$ and $p c h F$ are 71.3 and $71.9 \mathrm{~mol} \%$, respectively, with a strong bias for $\mathrm{G}$ or $\mathrm{C}$ at the third codon position $(87.1 \%$ for $p c h E$ and $89.4 \%$ for $p c h F)$ and the codon usage is typical of $P$. aeruginosa (Coyne \& Goldberg, 1995). The pchE gene extends for 4314 bp and its likely ATG start codon is preceded by a plausible ribosome-binding site (GGAG). The $p c h F$ gene consists of $5427 \mathrm{bp}$ and the predicted ATG start codon overlaps

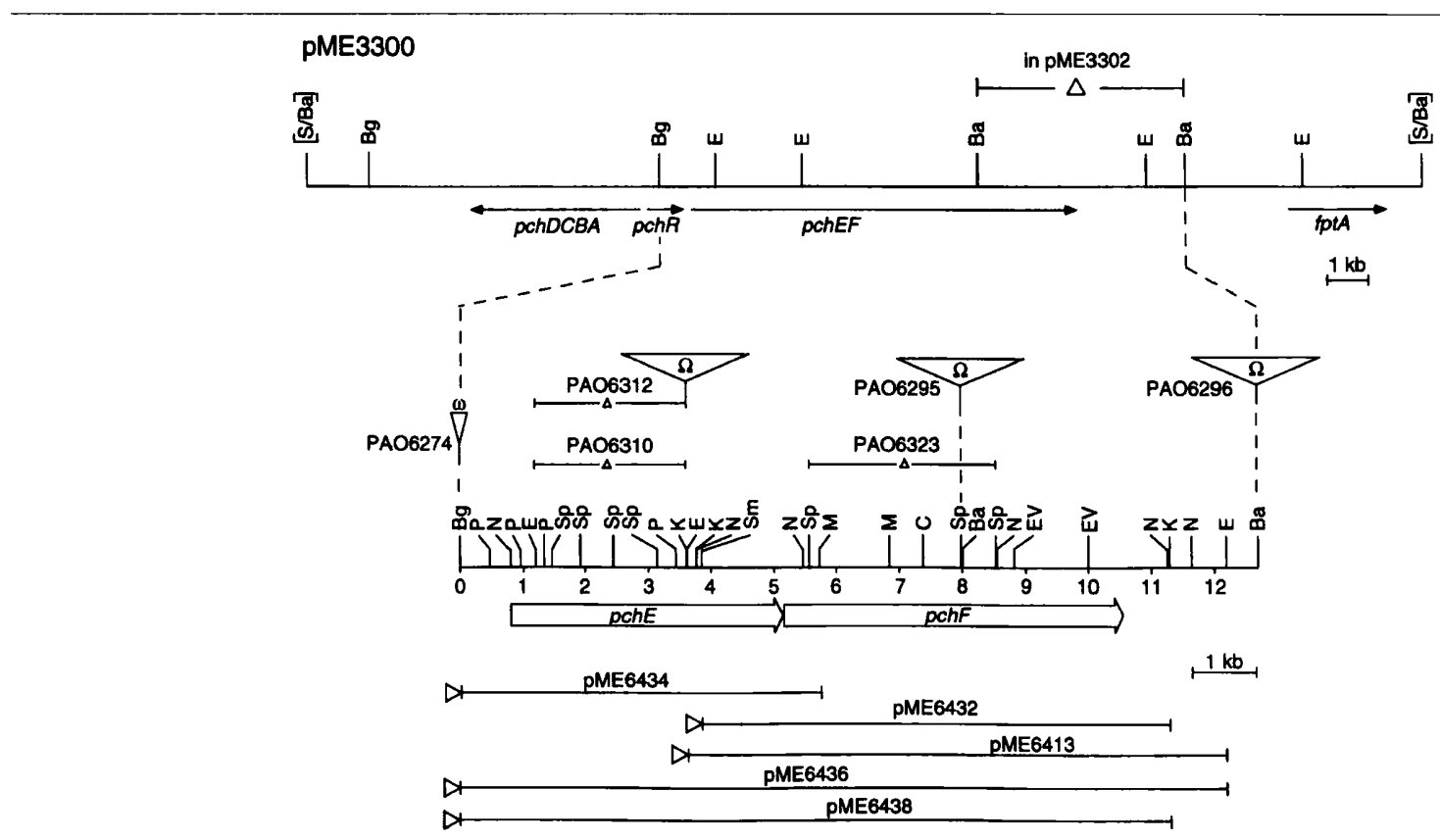

Fig. 1. Physical map of the pchDCBA-pchR-pchEF-fptA region of $P$. aeruginosa PAO1 present in cosmid pME3300. The pchDCBA operon, as well as the pchR and fptA genes have been described previously (Serino et al., 1997; Heinrichs \& Poole, 1993; Ankenbauer \& Quan, 1994). In plasmid pME3300 (Serino et al., 1995) the presence of pchR was confirmed by sequence analysis, that of fptA by restriction analysis. In plasmid pME3302, a deletion of a $3.3 \mathrm{~kb}$ BamHI fragment removed part of the $p c h F$ gene. The $\Omega S p / S m$ cassette (Prentki \& Krisch, 1984) present in the mutants PAO6312, PAO6295 and PAO6296 is designated by $\Omega$ in a triangle. Chromosomal regions deleted in the mutants PAO6310, PAO6312 and PA06323 are indicated by $\Delta$. The insertion of a $42 \mathrm{bp} \mathrm{BamHI}$ linker in the mutant PAO6274 is indicated by $\omega$ above a triangle. All subclones used for complementation experiments were constructed in the Pseudomonas vectors pUCPKS or pUCPSK such that the vector's lac promoter (indicated by $D$ ) is located upstream of pchE and pchF. The restriction enzymes used for subcloning are indicated as follows: Ba, BamHI; Bg, BgllI; C, Clal; E, EcoRI; EV, EcoRV; K, Kpnl; M, Munl; N, Ncol; P, Pstl; Sm, Smal; Sp, Sphl; S/Ba, Sau3ABamHI hybrid site. 
(a)

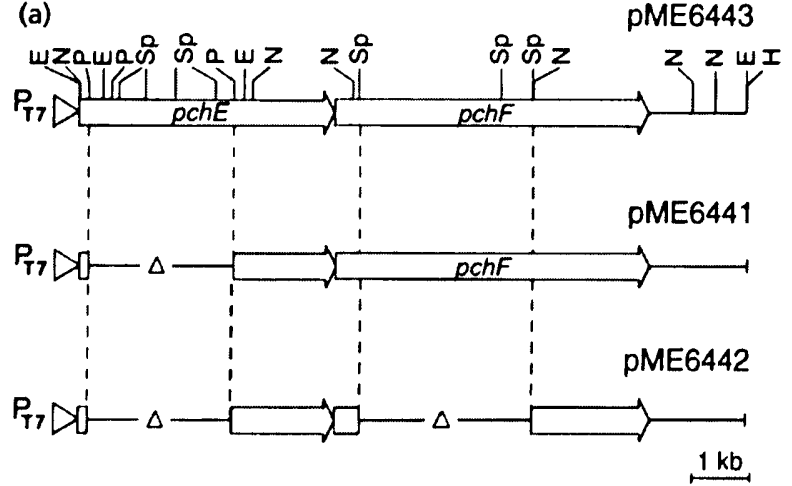

(b)
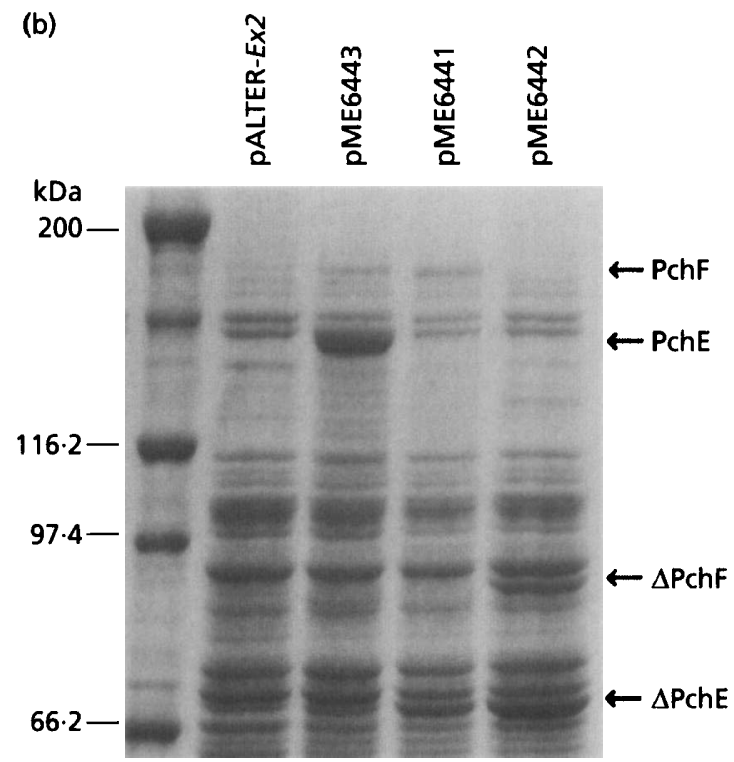

Fig. 2. Expression of pchE and pchF of $P$. aeruginosa. (a) The pchEF genes were inserted entirely or in part into the T7 expression vector pALTER-Ex2 using Ncol and a pBluescriptderived HindIII linker. Note that in pME6441, pME6442 and pME6443 the ATG start codon of pchE was placed downstream of a ribosome-binding site provided by the expression vector. This strong ribosome-binding site favours the expression of pchE over that of pchF. Moreover, T7 RNA polymerase moves much faster than the translating ribosomes (Lopez \& Dreyfus, 1996). For this reason, the long, distal pchF transcript might be particularly prone to degradation by RNases. As a consequence, the PchE protein band is stronger than the PchF band. The restriction enzymes are indicated as follows: $E, E$ coRl; $H$, HindIII; N, Ncol; P, Pstl; Sp, SphI. (b) SDS-polyacrylamide gel $\mathbf{( 7 . 5 \% )}$ of the proteins encoded by pchEF. $\triangle \mathrm{PchE}$ and $\triangle \mathrm{PchF}$ indicate truncated forms of PchE and PchF, respectively. Cultures of E. coli JM109(DE3) carrying the above plasmids were induced with IPTG.

with the TGA stop codon of $p c h E$. The putative ribosome-binding site (AGAG) of $p c h F$ is located at the $3^{\prime}$ end of pchE. The predicted proteins PchE and PchF consist of 1438 (156420 Da; pI 5.17) and $1809 \mathrm{aa}$ (197201 Da; pI 5.99), respectively. In reasonable agreement with these molecular mass values, polypeptides having apparent molecular masses of about 160 and $180 \mathrm{kDa}$ could be assigned to PchE and PchF, respectively, after overexpression in $E$. coli of $p c h E F$ from the T7 promoter on plasmid pME6443 (Fig. 2). Plasmid
pME6441 expressed PchF and a truncated form of PchE, due to an in-frame deletion of two Pstl fragments in pchE. Truncated forms of both PchE and PchF were expressed from pME6442, carrying an additional inframe deletion of two SphI fragments in $p c h F$ (Fig. 2). The PchE and PchF proteins could not be visualized when the T7 expression vector pALTER-Ex2 alone was used in a control experiment (Fig. 2) or when strain PAO1 was grown under iron limitation (data not shown).

\section{The deduced PchE and PchF proteins are similar to peptide synthetases}

The deduced amino acid sequences of PchE and PchF showed similarities to various peptide synthetases of bacterial origin. The greatest similarity was found to the High-Molecular-Weight Protein 2 (HMWP2), the irp2 gene product of Yersinia enterocolitica (37 and $31 \%$ identical amino acids in the full length PchE and PchF, respectively) and to the AngR protein of Vibrio anguillarum (31 and $27 \%$ identical amino acids in PchE and PchF, respectively). HMWP2 and AngR are involved in non-ribosomal biosynthesis of the thiazoline-containing siderophores yersiniabactin and anguibactin, respectively (Guilvout et al., 1993; Tomalsky et al., 1993; Bearden et al., 1997; Pelludat et al., 1998).

Because of these homologies and the characteristic modular structure of PchE and PchF (see Discussion), we propose that $p c h E$ and $p c h F$ encode peptide synthetases which could be involved in the condensation of salicylate with two molecules of cysteine.

\section{Roles of pchE and pchF in the sequential biosynthesis of Dha and pyochelin}

To study the biological functions of $p c h E$ and $p c h F$, we constructed chromosomal in-frame deletions in these genes via marker exchange using the suicide constructs pME6421 and pME6427 (Table 1) and strains were tested in GGP medium for production of salicylate, Dha and pyochelin. In the pchE mutant PAO6310 (Fig. 1), the $2.1 \mathrm{~kb}$ EcoRI deletion completely abolished the formation of both Dha and pyochelin and resulted in salicylate accumulation (Table 2). The mutant PAO6310 could be complemented with plasmid pME6434 carrying the $p c h E$ gene behind the lac promoter (Fig. 1; Table 2). We conclude that the $p c h E$ gene is necessary for the synthesis of Dha and pyochelin. In fact, the complemented mutant produced four times more Dha than did the wild-type PAO1 (Table 2), suggesting that the primary function of PchE could be to allow Dha synthesis. An in-frame deletion in $p c h F$ was constructed by deletion of two $S p h \mathrm{I}$ fragments of 0.55 and $2.4 \mathrm{~kb}$. Transfer of this mutation to the chromosome resulted in the $p c h F$ mutant PAO6323 (Fig. 1) which still formed salicylate and Dha, but was no longer able to synthesize pyochelin (Table 2), indicating that $p c b F$ is essential for pyochelin biosynthesis. Introduction of plasmid pME6432 (Fig. 1) expressing the $p c h F$ gene from a vector promoter fully restored pyochelin formation in 
Table 2. Effects of pchR, pchBA, pchE and pchF mutations on the synthesis of salicylate, Dha and pyochelin in P. aeruginosa

GGP medium $(30 \mathrm{ml})$ containing, when required, carbenicillin $\left(250 \mu \mathrm{g} \mathrm{m}^{-1}\right)$ was inoculated with $0.3 \mathrm{ml}$ culture grown in the same medium. After incubation at $37^{\circ} \mathrm{C}$ and 220 r.p.m. for $33 \mathrm{~h}$, supernatants were extracted and analysed for salicylate, Dha and pyochelin by HPLC (see Methods). The values given represent the means \pm SD of three independent experiments.

\begin{tabular}{|c|c|c|c|c|c|c|}
\hline Strain & Mutation & Plasmid & $\begin{array}{l}\text { Gene(s) } \\
\text { carried }\end{array}$ & $\begin{array}{c}\text { Salicylate } \\
\left(\mathrm{nmol} \mathrm{ml}^{-1}\right)^{*}\end{array}$ & 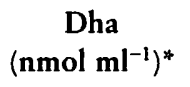 & $\begin{array}{c}\text { Pyochelin } \\
\left(\text { nmol ml } \mathbf{m}^{-1}\right)^{*}\end{array}$ \\
\hline PAO1 & Wild type & - & - & $1.4 \pm 0.2$ & $93 \cdot 6 \pm 25 \cdot 8$ & $838 \cdot 8 \pm 90 \cdot 6$ \\
\hline PAO6310 & pchE (non-polar) & - & - & $42 \cdot 1 \pm 3 \cdot 4$ & $<1 \cdot 2$ & $<2 \cdot 0$ \\
\hline PAO6310 & pchE (non-polar) & pME6434 & pchE & $2 \cdot 3 \pm 0.5$ & $381 \cdot 1 \pm 38 \cdot 1$ & $615 \cdot 5 \pm 125 \cdot 1$ \\
\hline PAO6312 & pchE (polar) & - & - & $38 \cdot 8 \pm 1 \cdot 1$ & $<1 \cdot 2$ & $<2 \cdot 0$ \\
\hline PAO6312 & pchE (polar) & pME6434 & $p c h E$ & $114 \cdot 8 \pm 30 \cdot 1$ & $139 \cdot 2 \pm 32 \cdot 6$ & $<2 \cdot 0$ \\
\hline PAO6312 & pchE (polar) & pME6436 & pchEF & $1 \cdot 8 \pm 0.6$ & $12 \cdot 7 \pm 2 \cdot 8$ & $574 \cdot 0 \pm 91 \cdot 9$ \\
\hline PAO6312 & pchE (polar) & pME6438 & PchEF & $1 \cdot 3 \pm 0 \cdot 3$ & $37 \cdot 1 \pm 6 \cdot 5$ & $<2 \cdot 0$ \\
\hline PAO6323 & $p c h F$ (non-polar) & - & - & $43 \cdot 2 \pm 1 \cdot 4$ & $3 \cdot 7 \pm 0 \cdot 6$ & $<2 \cdot 0$ \\
\hline PAO6323 & $p c h F$ (non-polar) & pME6432 & $p c h F$ & $45 \cdot 3 \pm 11 \cdot 0$ & $72 \cdot 1 \pm 16 \cdot 6$ & $704 \cdot 3 \pm 24 \cdot 1$ \\
\hline PAO6295 & $p c h F$ (polar) & - & - & $43 \cdot 2 \pm 3 \cdot 9$ & $3 \cdot 3 \pm 0.8$ & $<2 \cdot 0$ \\
\hline PAO6295 & $p c h F$ (polar) & pME6413 & $p c h F$ & $1118 \cdot 0 \pm 184 \cdot 5$ & $128 \cdot 0 \pm 18$ & $554 \cdot 7 \pm 71 \cdot 4$ \\
\hline PAO6295 & pchF (polar) & pME6432 & $p c h F$ & $308 \cdot 8 \pm 37 \cdot 9$ & $17 \cdot 6 \pm 3 \cdot 4$ & $<2 \cdot 0$ \\
\hline $\mathrm{PAO} 6274$ & $p c h R$ & - & - & $17 \cdot 1 \pm 2 \cdot 3$ & $<1 \cdot 2$ & $<2 \cdot 0$ \\
\hline PAO6297 & $p c h B A$ & - & - & $<0.04$ & $<1 \cdot 2$ & $<2 \cdot 0$ \\
\hline PAO6296 & $\boldsymbol{\Omega}$ insertion $\dagger$ & - & - & $0.9 \pm 0.5$ & $98 \cdot 1 \pm 26 \cdot 7$ & $861 \cdot 7 \pm 81 \cdot 4$ \\
\hline
\end{tabular}

*Content (ml culture supernatant) ${ }^{-1}$.

$\dagger$ This $\Omega$ insertion is located downstream of $p c h E F$ (Fig. 1).

PAO6323 (Table 2). The regulation of the pathway (discussed below) accounts for the relatively low amounts of Dha excreted by the $p c h F$ mutant PAO6323. In conclusion, these data are consistent with a linear biosynthetic pathway in which salicylate is first converted to Dha by PchE (hence designated Dha synthetase), followed by the transformation of Dha to pyochelin mediated essentially by PchF (designated pyochelin synthetase).

\section{pchE and pchF form a transcriptional unit}

The sequence organization of $p c b E$ and $p c b F$ points to an operon structure. To test this hypothesis, we constructed polar mutations in the chromosomal $p c h E$ and $p c h F$ genes by marker exchange using the suicide constructs pME6422 and pME6407 (Table 1). Insertion of an $\Omega \mathrm{Sm} / \mathrm{Sp}$ cassette at the site of the EcoRI deletion in $p c h E$ produced the mutant PAO6312 and an $\Omega \mathrm{Sm} / \mathrm{Sp}$ insertion at the unique $B a m H I$ site in $p c h F$ gave the mutant PAO6295 (Fig. 1). The polar pchE mutant PAO6312 was unable to form Dha and pyochelin, as expected (Table 2). Introduction of the pchE-carrying plasmid pME6434 complemented this polar mutant for the production of Dha but not for pyochelin, indicating that $p c h E$ and $p c h F$ are indeed organized as an operon. The polar pchE mutant PAO6312 could be complemented for pyochelin production by plasmid pME6436 which carries $p c h E F$ plus an additional $1.6 \mathrm{~kb}$ fragment downstream of $p c h F$ (Fig. 1). The Dha levels remained rather low in strain PAO6312(pME6436), perhaps because of a channeling effect. The polar $p c h F$ mutant PAO6295 did not produce pyochelin and formed small amounts of Dha. Plasmid pME6413 carrying pchF plus the $1.6 \mathrm{~kb}$ fragment downstream of $p c h F$ restored pyochelin formation and also increased the levels of salicylate and Dha produced (Table 2).

The polar pchE mutant PAO6312 was not complemented for pyochelin production by a plasmid, pME6438, carrying only pchEF (Fig. 1, Table 2). Similarly, the polar $p c h F$ mutant PAO6295 was not restored for pyochelin synthesis by a plasmid, pME6432, expressing only $p c h F$ (Fig. 1, Table 2). These observations indicate that the $p c h E F$ transcriptional unit contains one or more additional genes downstream of $p c h F$ which participate in the production of pyochelin. The nucleotide sequence downstream of $p c h F$ indicates the presence of an ORF of $>742 \mathrm{nt}(p c h G)$ whose biochemical function is unknown at present. An $\Omega \mathrm{Sm} / \mathrm{Sp}$ insertion constructed $2.0 \mathrm{~kb}$ downstream of the $3^{\prime}$ end of $p c h F$, in strain PAO6296 (Fig. 1), had no effect on the production of salicylate, Dha and pyochelin (Table 2) and may thus lie outside of the extended $p c h E F$ transcriptional unit.

Finally, the role of salicylate as a precursor of Dha and pyochelin (Ankenbauer \& Cox, 1988; Serino et al., 1997) was confirmed by the construction of the $p c h B A$ deletion mutant PAO6297, using pME6156 for delivery of the $1.0 \mathrm{~kb}$ deletion to the chromosomal $p c h B A$ genes 
Table 3. Regulation of pchEF by iron, Fur and PchR

Plasmid pME6425 carrying a $p c h E^{\prime}-{ }^{\prime}$ lac $Z$ fusion was introduced into each strain. DCAA medium $(50 \mathrm{ml})$ was inoculated with $10 \mu \mathrm{l}$ of a culture grown in nutrient yeast broth containing tetracycline and grown at $37^{\circ} \mathrm{C}$ and 220 r.p.m. for 15 h to $\mathrm{OD}_{600} \approx 0.8$. $-\mathrm{Fe}$, no iron; $+\mathrm{Fe}$, medium supplemented with $100 \mu \mathrm{M} \mathrm{FeCl}_{3}$ (iron excess). $\beta$-Galactosidase activities are expressed in thousands of Miller units $(\mathrm{kU})$ and are mean values from three experiments $\pm S D$.

\begin{tabular}{|lccc|}
\hline Strain & Genotype & \multicolumn{2}{c|}{$\begin{array}{c}\beta \text {-Galactosidase } \\
\text { activity (kU) }\end{array}$} \\
\cline { 3 - 4 } & & $-\mathrm{Fe}$ & $+\mathrm{Fe}$ \\
\hline PAO1 & Wild type & $4.79 \pm 0.09$ & $<0.01$ \\
PAO1A4 & fur-4 & $9.97 \pm 1.04$ & $1.86 \pm 0.46$ \\
PAO6274 & pchR & $<0.01$ & $<0.01$ \\
\hline
\end{tabular}

(Table 1). Strain PAO6297 was devoid of salicylate, Dha and pyochelin (Table 2). Addition of salicylate restored pyochelin production, whereas addition of Dha did not (data not shown). Thus, salicylate can cross-feed a salicylate-negative mutant, in agreement with the results of Ankenbauer \& Cox (1988), whereas external Dha cannot enter the pyochelin pathway, perhaps because of a permeability barrier.

\section{Expression of pchEF is repressed by iron with Fur and positively controlled by PchR}

The $p c h E$ promoter is presumed to be located directly downstream of the $p c h R$ gene (Heinrichs \& Poole, 1993; Fig. 1). A sequence strongly resembling the consensus Fur (ferric uptake regulator) binding site (Calderwood \& Mekalanos, 1987; Fig. 3) was found 45 bp upstream of the ATG start codon of the $p c h E$ gene, suggesting that $p c h E F$ may be iron-regulated. This hypothesis was tested using strain PAO1(pME6425) ( $p c h E^{\prime}-{ }^{\prime} l a c Z$ ) in DCAA medium. This medium is iron-deficient, limiting growth of $P$. aeruginosa to low cell densities corresponding to $\mathrm{OD}_{600} \approx 0.5-1.0$ and consequently low yields of Dha and pyochelin are obtained (data not shown). By contrast, the GGP medium used for the excretion experiments above (Table 2) allows high cell yields and iron availability appears to be less restricted than in DCAA medium.

The expression of the $p c h E^{\prime}-l a c Z$ fusion was strongly repressed when DCAA medium was supplemented with $100 \mu \mathrm{M} \mathrm{FeCl}_{3}$, whereas high expression was observed during iron limitation (Table 3). In the Fur mutant PAO1A4 grown under iron-limitation, the $p c h E^{\prime}-l a c Z$ expression level was twofold higher than that obtained in PAO1. After iron addition, the expression of $p c h E^{\prime}-{ }^{\prime} l a c Z$ was partially derepressed, as expected for this leaky Fur mutant (Barton et al., 1996). Thus, Fur is responsible for iron repression of $p c h E$ expression. By analogy with the $p c h D, p c h R$ and $f p t A$ promoters (Serino et al., 1997; Heinrichs \& Poole, 1993, 1996), we postulate that Fur repression of $p c h E$ is mediated via the Fur box upstream of $p c h E$ (Fig. 3).

To test whether expression of the $p c h E F$ genes depends on the transcriptional regulator PchR, we constructed the mutant PAO6274 (Fig. 1) by marker exchange using the suicide construct pME3384 which carries within the $p c h R$ gene a linker having translation stops in all three reading frames. This $p c h R$ mutant produced some salicylate but failed to excrete measurable amounts of Dha and pyochelin (Table 2). No expression of the translational $p c h E^{\prime}-{ }^{\prime} l a c Z$ fusion on pME6425 was observed in the $p c h R$ mutant (Table 3), implying that PchR is essential for expression of the $p c h E F$ genes.

\section{Pyochelin induces the expression of the pchEF and pchDCBA operons}

Extracellular pyochelin (or ferric pyochelin) is known to be required for expression of the $p c h R$ regulator and the fptA receptor genes (Heinrichs \& Poole, 1993, 1996; Ankenbauer \& Quan, 1994). Therefore, we tested whether pyochelin also plays a role in the expression of the $p c h E F$ and $p c h D C B A$ operons. $p c h E^{\prime}-{ }^{\prime} l a c Z$ activity was about 100-fold lower in the pchE mutant PAO6310 and in the $p c h F$ mutant PAO6323 than in the wild-type PAO1 growing in GGP medium (Table 4). Low level $p c h E^{\prime}-{ }^{\prime} l a c Z$ expression was also found in the $p c h B A$ deletion mutant PAO6297. No $\beta$-galactosidase activity was detected in a $p c h R$-negative background (strain PAO6274; Table 4). Since none of the four mutants was able to produce pyochelin (Table 2), these data suggest that either pyochelin or its precursors (salicylate and Dha) could be responsible for high-level $p c h E^{\prime}-l a c Z$ expression in strain PAO1. Therefore, salicylate, Dha, or pyochelin was added to the culture medium. Salicylate induced $p c h E^{\prime}-{ }^{\prime} l a c Z$ expression about 15 -fold in the pchBA-negative mutant PAO6297, whereas no increase was observed in the other mutants PAO6310, PAO6323 and PAO6274 (Table 4). Since addition of salicylate to the growth medium restores pyochelin formation to the $p c h B A$ mutant, the inducing compound may not be salicylate itself but its products Dha or pyochelin. Dha added to the culture medium had no effect on $p c h E^{\prime}-l a c Z$ expression in any of the strains tested (Table 4). By contrast, when the growth medium was amended with pyochelin, $p c h E^{\prime}-{ }^{\prime} l a c Z$ expression was induced about 100-fold in strains PAO6310, PAO6323 and PAO6297, but not in the $p c h R$ mutant PAO6274. We conclude that pyochelin (or ferric pyochelin), together with the PchR protein, is required for high-level expression of the $p c h E F$ operon. This fact helps explain the rather small amounts of Dha detected in supernatants of the $p c h F$ mutants PAO6323 and PAO6295 (Table 2): due to the absence of the inducer pyochelin, expression of $p c h E$ was low in these $p c h F$ mutants and therefore little Dha was made.

Pyochelin also induced the $p c h D C B A$ operon, as shown by experiments using a translational $p c h D^{\prime}-{ }^{\prime} l a c Z$ fusion on plasmid pME6122 (Table 4). In the $p c h E, p c h F$, $p c h B A$ and $p c h R$ mutants, the $\beta$-galactosidase levels 


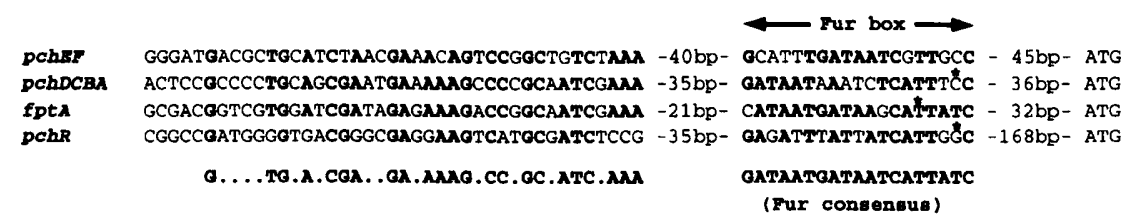

Fig. 3. Fur recognition sequences in the promoter regions of $p c h R, f p t A, p c h D C B A$ and pchEF. The locations of the Fur boxes are indicated relative to the ATG initiation codons. Transcriptional start sites mapped in this region (Serino et al., 1997; Ankenbauer \& Quan, 1994) are marked by asterisks. Bold letters in the Fur boxes represent nucleotides matching those in the Fur binding consensus sequence of $E$. coli (Calderwood \& Mekalanos, 1987). Conserved nucleotides (bold letters) upstream of the Fur box in the four promoters might be involved in PchR binding.

Table 4. Effects of salicylate, Dha and pyochelin on the expression of pchE'-'lacZ and pchD'-'lacZ translational fusions

GGP culture medium ( $15 \mathrm{ml}$ ) containing tetracycline (for maintenance of pME6425) or carbenicillin (for pME6122) was inoculated with $0.15 \mathrm{ml}$ of a culture grown in the same medium and incubated at $37^{\circ} \mathrm{C}$ and 220 r.p.m. for 24 h. Salicylate, Dha or pyochelin were added to the culture medium at the following final concentrations: salicylate, $3.6 \mu \mathrm{M}$; (S)-Dha, $44.8 \mu \mathrm{M}$; pyochelin, $102 \mu \mathrm{M}$. Values shown are the means of duplicate experiments. Variation between parallel measurements was $<20 \%$ in general. $\mathrm{BD}$, Below the limit of detection ( $<5$ Miller units). $\beta$-Galactosidase activity is expressed in thousands of Miller units $(\mathrm{kU})$.

\begin{tabular}{|c|c|c|c|c|c|}
\hline \multirow[t]{2}{*}{ Strain/plasmid } & \multirow{2}{*}{$\begin{array}{c}\text { Chromosomal } \\
\text { marker }\end{array}$} & \multicolumn{4}{|c|}{$\beta$-Galactosidase activity $(\mathbf{k U})$} \\
\hline & & - & +Salicylate & $+(S)$-Dha & + Pyochelin \\
\hline PAO1(pME6425) & - & $20 \cdot 4$ & $22 \cdot 0$ & $18 \cdot 5$ & $25 \cdot 8$ \\
\hline PAO6310(pME6425) & $p c h E$ & $0 \cdot 2$ & $0 \cdot 2$ & $0 \cdot 3$ & $24 \cdot 6$ \\
\hline PAO6323(pME6425) & $p c h F$ & $0 \cdot 2$ & $0 \cdot 2$ & $0 \cdot 2$ & $24 \cdot 2$ \\
\hline PAO6297(pME6425) & $p c h B A$ & $0 \cdot 2$ & $3 \cdot 3$ & $0 \cdot 2$ & $23 \cdot 5$ \\
\hline PAO6274(pME6425) & $p c h R$ & $\mathrm{BD}$ & BD & $\mathrm{BD}$ & BD \\
\hline PAO1(pME6122) & - & $23 \cdot 0$ & $33 \cdot 2$ & $23 \cdot 6$ & $27 \cdot 9$ \\
\hline PAO6310(pME6122) & $p c h E$ & 0.7 & $0 \cdot 9$ & $0 \cdot 9$ & $34 \cdot 8$ \\
\hline PAO6323(pME6122) & $p c h F$ & 0.9 & $0 \cdot 7$ & $0 \cdot 9$ & $32 \cdot 2$ \\
\hline PAO6297(pME6122) & $p c h B A$ & $0 \cdot 9$ & $5 \cdot 5$ & $1 \cdot 1$ & $38 \cdot 8$ \\
\hline PAO6274(pME6122) & $p c h R$ & $0 \cdot 8$ & $0 \cdot 7$ & 0.8 & $0 \cdot 6$ \\
\hline
\end{tabular}

were reduced 30 -fold compared to the expression observed in the wild-type PAO1 (Table 4). Addition of pyochelin to the $p c h E, p c h F$ and $p c h B A$ mutants restored the expression to wild-type levels. Addition of salicylate to the growth medium of the $p c h B A$-negative mutant PAO6297 carrying pME6122 induced $\beta$-galactosidase activity about sevenfold but had no effect on the other mutants tested. Again, Dha had no effect on $p c h D^{\prime}-{ }^{\prime} l a c Z$ expression (Table 4). Whereas PchR was strictly required for the expression of $p c h E F$, this regulator appears to be less important for the expression of the $p c h D C B A$ operon in that a basal expression of the $p c h D^{\prime}-{ }^{\prime} l a c Z$ fusion was observed in the absence of PchR or pyochelin (Table 4). In fact, the $p c h R$ mutant PAO6274 produced some salicylate, but no Dha and pyochelin (Table 2).

Previously, we have demonstrated Fur-dependent repression of the $p c h D C B A$ operon by iron (Serino et al.,
1997). Taken together, our results show that the $p c h D C B A$ and $p c h E F$ genes are regulated in parallel: negatively by iron and positively by pyochelin, the end product of the pathway.

\section{DISCUSSION}

\section{Evidence for a linear chorismate-salicylate-Dha- pyochelin pathway in $P$. aeruginosa}

The $p c h E F$ transcriptional unit characterized in this study extends the pyochelin biosynthetic gene region described previously which consists of the $p c h R$ regulatory gene (Heinrichs \& Poole, 1993) and the $p c h D C B A$ operon (Serino et al., 1995, 1997). Pyochelin is structurally related to the siderophores yersiniabactin of $Y$. enterocolitica and anguibactin of V. anguillarum. These three siderophores have a common Dha core (reviewed 


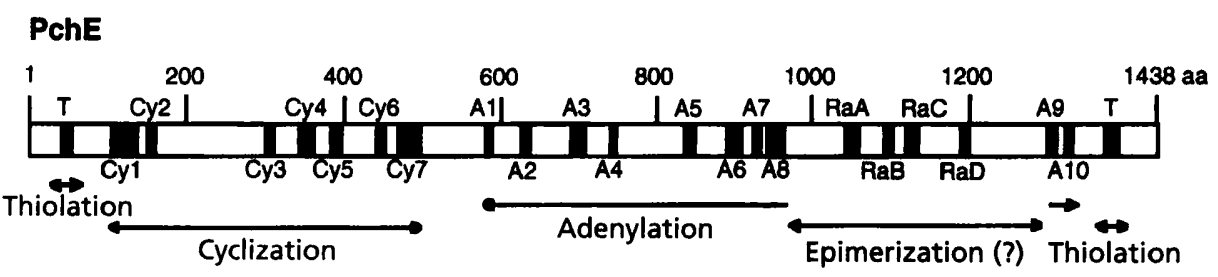

PchF

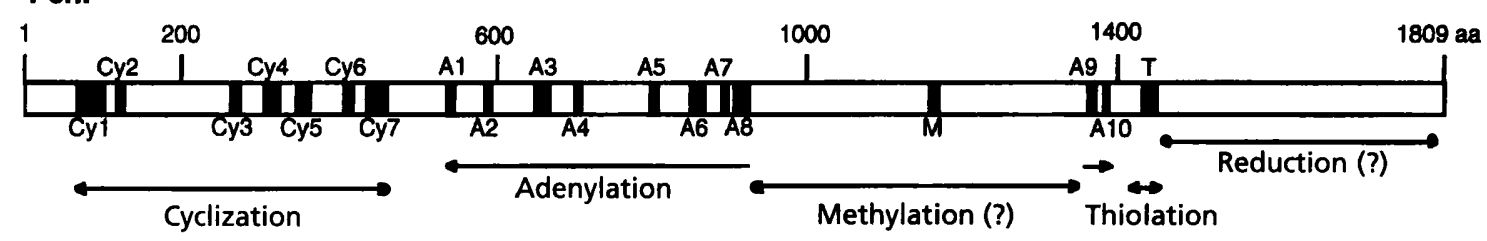

\section{Adenylation domains}

\begin{tabular}{|c|c|c|}
\hline $\begin{array}{l}\text { PchE } \\
\text { A1 } \\
\text { PChF }\end{array}$ & $\begin{array}{r}580 \\
1 \\
540\end{array}$ & $\begin{array}{ll}V T \text { RGEL } & 585 \\
\mathrm{~L}(T S) \text { YXEL } & 6 \\
\mathrm{Y} \text { S YRQV } & 545\end{array}$ \\
\hline $\begin{array}{l}\text { PChE } \\
\text { A2 } \\
\text { PChF }\end{array}$ & $\begin{array}{r}624 \\
1 \\
584\end{array}$ & $\begin{array}{lllll}\text { VLAAGACY } & \mathrm{P} & \mathrm{L} & \mathrm{D} & 635 \\
\text { LKAG. AYL (VL) } & \mathrm{P}(\mathrm{LI}) & \mathrm{D} & 12 \\
\text { ILQAGAAY } \mathrm{V} & \mathrm{P} & \mathrm{V} & \mathrm{D} & 595\end{array}$ \\
\hline $\begin{array}{l}\text { PchE } \\
\text { A3 } \\
\text { PChF }\end{array}$ & $\begin{array}{r}691 \\
1 \\
654\end{array}$ & $\begin{array}{lll}\text { SAYVIYTSG S } & \text { TGVPKG } & 706 \\
\text { LAY. .YTSG (ST) TG. PKG } & 16 \\
\text { LAYVIYTSG S } & \text { TGTPKG } & 669\end{array}$ \\
\hline $\begin{array}{l}\text { PchE } \\
\text { A4 } \\
\text { PChF }\end{array}$ & $\begin{array}{r}741 \\
1 \\
704\end{array}$ & $\begin{array}{ll}\text { FDLS } & 744 \\
\text { FD.S } & 4 \\
\text { EDLS } 707\end{array}$ \\
\hline $\begin{array}{l}\text { PChE } \\
\text { A5 } \\
\text { PChF }\end{array}$ & $\begin{array}{r}837 \\
1 \\
801\end{array}$ & $\begin{array}{ll}\text { VLGGATE } & 844 \\
\text { N.YGPTE } & 7 \\
\text { QPGRRIE } 807\end{array}$ \\
\hline $\begin{array}{l}\text { PchE } \\
\text { A6 } \\
\text { PchF }\end{array}$ & $\begin{array}{r}890 \\
1 \\
854\end{array}$ & $\begin{array}{lll}\text { GELWIGGAS } & \text { L ARGYR } & 904 \\
\text { GEL.I.G.G(VL) ARGYL } & 15 \\
\text { GEIHIGGVG } & \text { L ALGYA } & 868\end{array}$ \\
\hline $\begin{array}{l}\text { PChE } \\
\text { A7 } \\
\text { PChF }\end{array}$ & $\begin{array}{r}923 \\
1 \\
888\end{array}$ & $\begin{array}{lll}X \quad B & \text { TGDR } & 928 \\
Y(R K) & \text { TGDL } 6 \\
Y \text { B } & \text { TGDL } & 893\end{array}$ \\
\hline $\begin{array}{l}\text { PChE } \\
\text { A8 } \\
\text { PChF }\end{array}$ & $\begin{array}{r}941 \\
1 \\
906\end{array}$ & $\begin{array}{ll}\text { GRVDQOVKVRGORIELGEVE } & 960 \\
\text { GR.D.QVKIRG. RIELGEIE } & 20 \\
\text { GREDDOVKIRGHRIELAELD } & 925\end{array}$ \\
\hline $\begin{array}{l}\text { PChE } \\
\text { A } 9 \\
\text { PChF }\end{array}$ & $\begin{array}{r}1303 \\
1 \\
1361\end{array}$ & $\begin{array}{lll}\text { LPQAM R } & \text { P } 1309 \\
\text { LP.YM (IV) } & 7 \\
\text { VRRYM L } & \text { P } 1367\end{array}$ \\
\hline $\begin{array}{l}\text { PchE } \\
\text { A } 10 \\
\text { PchF }\end{array}$ & $\begin{array}{r}1323 \\
1 \\
1381\end{array}$ & 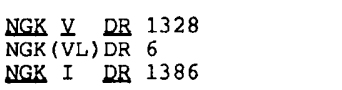 \\
\hline
\end{tabular}

Thiolation domains

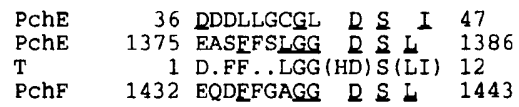

\section{Cyclization domains}

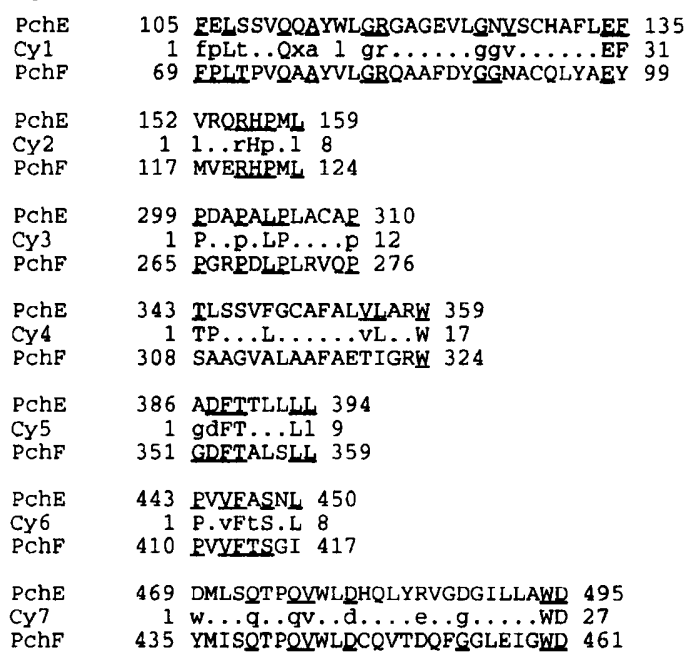

\section{Methylation domain}
PChE 1161 LLELGAGTA 1169
M 1 VLDIGGGTG
IVEV C P
L

\begin{tabular}{|c|c|c|c|}
\hline \multicolumn{4}{|c|}{ Epimerization domain } \\
\hline $\begin{array}{l}\text { PchE } \\
\text { RaA }\end{array}$ & $\begin{array}{r}1059 \\
1\end{array}$ & $\begin{array}{l}\text { ALRRLGWQAALTAMG } \\
\text { AY.TE. NDILLTA.G }\end{array}$ & $\begin{array}{l}1073 \\
15\end{array}$ \\
\hline $\begin{array}{l}\text { PchE } \\
\text { RaB }\end{array}$ & $\begin{array}{r}1105 \\
1\end{array}$ & $\begin{array}{l}\text { LPDGREALAR } 1114 \\
\text { EGHGRE. IIE } 10\end{array}$ & \\
\hline $\begin{array}{l}\operatorname{Pch} E \\
\operatorname{RaC}\end{array}$ & $\begin{array}{r}1136 \\
1\end{array}$ & $\begin{array}{l}\text { BAGLWLDQGMASLLR } \\
\text { RTVGWFTSMYP . . LD }\end{array}$ & $\begin{array}{l}1150 \\
15\end{array}$ \\
\hline $\begin{array}{l}\mathrm{chE} \\
\mathrm{aD}\end{array}$ & $\begin{array}{r}1188 \\
1\end{array}$ & $\begin{array}{l}\text { AEHLGRYD } 1195 \\
\text { FNYLGQFD } 8\end{array}$ & \\
\hline
\end{tabular}

Fig. 4. Modular structures of PchE and PchF. Conserved sequence motifs in the predicted cyclization (Cy), adenylation (A), thiolation (T), epimerization (Ra) and methylation (M) domains (Marahiel, 1997; Konz et al., 1997; Stachelhaus \& Marahiel, 1995; Haese et al., 1993) are indicated. Note that the proposed adenylation, condensation/cyclization and thiolation domains of PchE and PchF appear to be sufficiently conserved to justify their assignments. The epimerization, methylation and reduction domains proposed are more speculative.

by Konz et al., 1997). The salicylate moiety of the core can be hydroxylated (in the case of anguibactin) or additional amino acid residues can be added to Dha (in the case of pyochelin and yersiniabactin). The sequence similarities of the deduced PchE and PchF proteins with the peptide synthetases HMWP2 of yersiniabactin bio- 
synthesis and AngR of anguibactin biosynthesis (reviewed by Zocher \& Keller, 1997; Marahiel, 1997) clearly indicate that Dha and pyochelin are formed by a non-ribosomal, thiotemplate mechanism. Genetic and in vivo biochemical data obtained here allow us to assign unequivocal biosynthetic functions to PchE and $P c h F$ of $P$. aeruginosa. Mutants blocked in the $p c h F$ gene (PAO6323, PAO6295) are unable to produce pyochelin but excrete Dha. Mutants impaired in $p c h E$ function are deficient in both Dha and pyochelin. A polar $p c h E$ mutant (PAO6312) complemented with $p c h E^{+}$, which is able to express PchE but not PchF, produces Dha but lacks pyochelin. A non-polar pchE mutant (PAO6310) is restored for production of Dha and pyochelin by complementation with $p c h E^{+}$(Table 2). Thus, PchE is needed to synthesize Dha from salicylate and PchF is required to synthesize pyochelin from Dha. In this linear pathway, the functions of the $p c h E F$ genes are confirmed by heterologous expression in $P$. fluorescens P3: strain P3 carrying pME3300 ( $\left.p c h R^{+} p c h D C B A^{+} p c h E F^{+}\right)$ produces salicylate, Dha and pyochelin, whereas strain P3 carrying pME3302 ( $\left.p c h R^{+} p c h D C B A^{+} p c h E^{+} F^{-}\right)$ produces salicylate and Dha.

\section{PchE and PchF are members of the large group of multifunctional peptide synthetases}

Sequence analysis of PchE and PchF revealed modular protein structures that are typical of peptide synthetases (Marahiel, 1997; Zocher \& Keller, 1997). Peptide synthetases are large proteins consisting of different modules, each of which is responsible for the activation and incorporation of a single amino acid into the final peptide (Marahiel, 1997; Konz et al., 1997). Typical modules consist of an acylation (A) domain (about $550 \mathrm{aa})$, which recognizes and activates the substrate amino acid and a thiolation (T) domain (about $100 \mathrm{aa}$ ) carrying the cofactor $4^{\prime}$-phosphopantetheine bound to a conserved serine residue. The thiol group of the cofactor undergoes thioester bond formation with the activated amino acid. A third domain of about $350 \mathrm{aa}$, termed condensation $(\mathrm{C})$ domain, is involved in peptide bond formation. In addition, peptide synthetases may have tailoring domains such as an epimerization domain (about $400 \mathrm{aa}$ ) or a $\mathrm{N}$-methylation domain (about $420 \mathrm{aa}$ ) when incorporated amino acids are modified correspondingly (Marahiel, 1997).

The deduced amino acid sequences of PchE and PchF revealed acylation domains in which most of the typical motifs (A1-A10) described by Marahiel (1997) are conserved (Fig. 4). Thiolation domains containing invariant serine residues were found in both PchE (Ser46 and Ser-1385) and PchF (Ser-1442). A putative cyclization domain with well-conserved sequence motifs Cy1-Cy7 was identified in the N-terminal parts of both PchE and PchF (Fig. 4). This specialized form of condensation domain is assumed to catalyse both peptide bond formation using activated cysteine and cyclization of cysteine, resulting in thiazoline ring formation (Konz et al., 1997). Between sequence motifs
A8 and A9 of the acylation domains in PchE and PchF, putative tailoring domains are inserted. Sequence comparison of the respective domain in PchE (aa 960-1300) revealed $30 \%$ identity with amino acid residues of ALR2, an alanine racemase of E. coli (Lobocka et al., 1994), suggesting that this domain might be responsible for epimerization of $\mathrm{L}$-cysteine to the $\mathrm{D}$-form. Sequence motifs characteristic of epimerization domains of other peptide synthetases (Stachelhaus \& Marahiel, 1995) were located between aa 1059 and 1195 of PchE (Fig. 4); however, their conservation was rather weak. The tailoring domain of PchF contains the sequence motif LLELGAGTA (M; Fig. 4) which resembles the signature sequence VLE/DXGXGXG described for $S$-adenosylmethionine-dependent methyltransferases (Haese et al., 1993). However, the last glycine residue, which is usually conserved in these enzymes, is lacking from the sequence motif in PchF. The C-terminal part of PchF had $33 \%$ identical amino acids in a 117 aa overlap with an alcohol dehydrogenase from Alcaligenes eutrophus (Jendrossek et al., 1988). This additional domain of PchF, which has no counterpart in PchE, might carry out the reduction of the second thiazoline ring of pyochelin.

These structural considerations and the biochemical properties of the $p c h D C B A$ and $p c h E F$ mutants (Serino et al., 1995, 1997; this study) lead us to propose a model for the pyochelin pathway in $P$. aeruginosa (Fig. 5). This model is strongly inspired by the elegant biochemical work on the enzymes of enterobactin biosynthesis in $E$. coli (Gehring et al., 1997, 1998).

The initial steps of the pathway, the conversion of chorismate to salicylate (Serino et al., 1995), are catalysed by isochorismate synthase (PchA) and isochorismate-pyruvate lyase (PchB). These enzymic reactions do not require organic cofactors (C. Gaille, C. Reimmann \& D. Haas, unpublished data). Salicylate is thought to be adenylated by PchD (Serino et al., 1997), which is similar to 2,3-dihydroxybenzoate-AMP ligase (EntE) of E. coli (Rusnak et al., 1989). Activated salicylate is then expected to be anchored, as a thioester, on a thiol template. This reaction may occur by a mechanism which has been studied in detail in the enterobactin pathway where the EntE enzyme transfers activated 2,3-dihydroxybenzoate (or its analogue salicylate) to phosphopantetheinylated EntB (Gehring et al., 1997). In pyochelin synthesis, PchE has an obligatory role in the conversion of salicylate to Dha (Table 2) and, therefore, is a logical candidate for accepting activated salicylate. PchE has two putative acceptor sites at serine residues 46 and 1385 (Fig. 4), both of which could be modified by a $4^{\prime}$-phosphopantetheinyl group. Either acceptor site could form the postulated salicylate thioester. The model (Fig. 5) further predicts that the PchE protein will activate and fix one molecule of cysteine (probably the L-isomer) at the second acceptor site. PchE could then couple the activated carboxy group of salicylate to the amino group of fixed cysteine, in an amide-bond-forming reaction. The domain structure of PchE also suggests that this protein may carry out cyclization (thiazoline formation) and isomerization of 


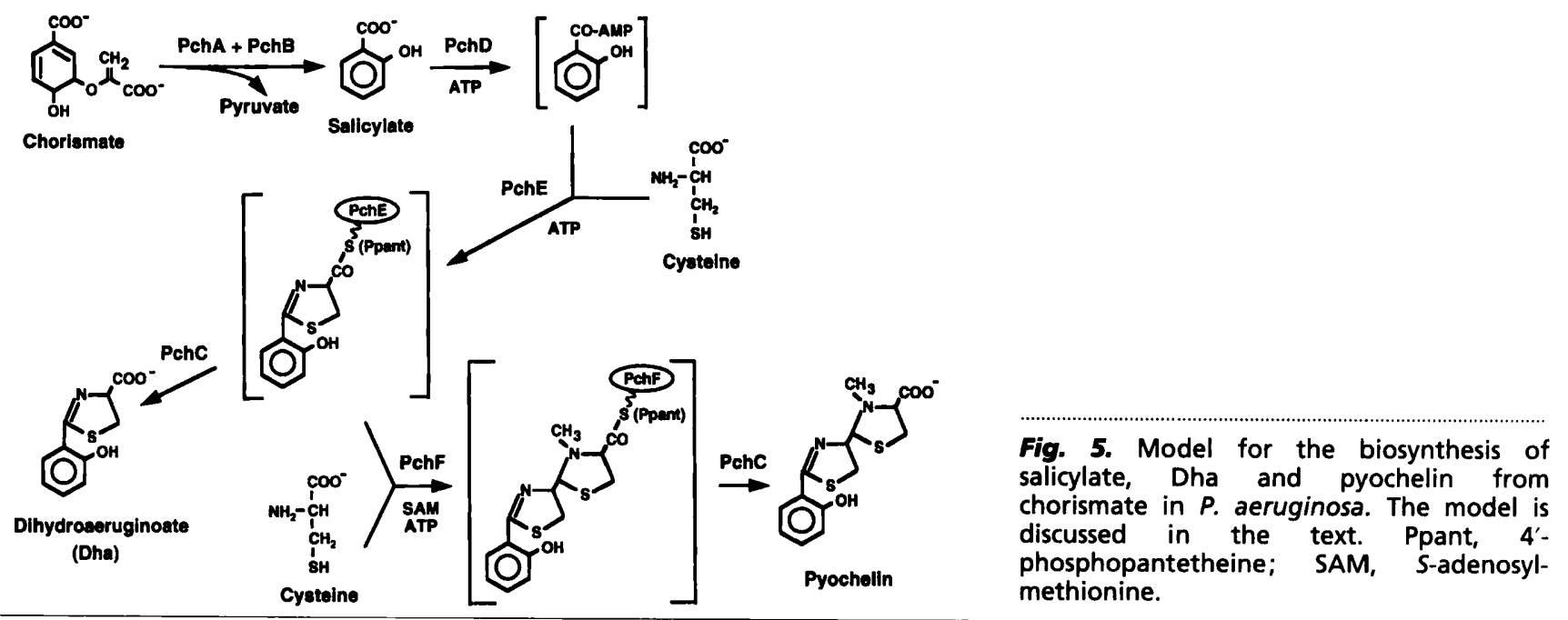

cysteine. Release of the reaction product from the PchE template by a thioesterase will yield $(S)$-Dha. This isomer has been identified as a natural product in $P$. fluorescens PFM2 (Carmi et al., 1994) and as a constituent of pyochelin in P. aeruginosa (Rinehart et al., 1995). In P. aeruginosa the stereochemistry of free Dha has not yet been worked out. The thioesterase function is probably provided by PchC (Serino et al., 1997).

In the wild-type PAO1 only small amounts of Dha are released, the bulk being converted to pyochelin (Table 2). The model in Fig. 5 predicts that PchE-bound Dha reacts with L-cysteine carried by the PchF protein at the phosphopantetheinylated serine residue 1442 . Further tasks of PchF may be the cyclization of cysteine, the reduction of the thiazoline ring and $N$-methylation of the thiazolidine ring formed (Fig. 5); admittedly, the PchF sequence provides only limited evidence for reduction and methylation functions. Release of pyochelin from PchF may be mediated either by the putative PchC thioesterase or by a potential thioesterase domain in PchF (not shown). A similar situation exists in surfactin synthesis of Bacillus subtilis where a thioesterase domain of surfactin synthetase 3 and a separate thioesterase protein cooperate in surfactin synthesis (Schneider \& Marahiel, 1998).

Two important aspects of pyochelin biosynthesis are not addressed by the present model (Fig. 5). First, no pyochelin pathway-specific phosphopantetheinyl transferase gene has yet been identified. In enterobactin synthesis, a specialized phosphopantetheinyl transferase (EntD) attaches the cofactor to EntB and to EntF (Gehring et al., 1997), whereas transferases involved in other non-ribosomal peptide syntheses may display cross-pathway activities (Marahiel, 1997; Ku et al., 1997). Second, it is unclear whether active transport is required to export pyochelin and Dha. In pyoverdin biosynthesis of $P$. aeruginosa, the $p v d E$ gene is assumed to have an ATP-dependent pyoverdin export function (McMorran et al., 1996). The genomic region located between the $p c h F$ and $f p t A$ genes (Fig. 1) might harbour some of the missing $p c h$ genes.

\section{Positive autoregulation of pyochelin biosynthesis}

The expression of both the $p c h D C B A$ and $p c h E F$ genes was positively controlled by extracellular pyochelin or ferric pyochelin. In different pyochelin-negative mutants, expression occurred at a low basal level unless pyochelin was added. The $p c h D^{\prime}-{ }^{\prime} l a c Z$ and $p c h E^{\prime}-{ }^{\prime} l a c Z$ fusions were induced 30 - and 100 -fold, respectively and induction depended on a functional PchR protein (Table 4). Previously, pyochelin-dependent expression has been reported for the pyochelin receptor FptA and the PchR regulator itself (Heinrichs \& Poole, 1993, 1996). The nucleotide sequences upstream of the Fur box in the $p c h E, p c h D, p c h R$ and $f p t A$ promoters showed a number of conserved nucleotides (Fig. 3), some of which might be involved in PchR recognition. Induction of the outermembrane receptors by specific siderophores present in the medium is common in pseudomonads (Crosa, 1997). It could be argued that Pseudomonas strains which take up extracellular (ferric) pyochelin by inducing a specific receptor would have no need to synthesize pyochelin de novo. In the case of $P$. aeruginosa, such a view is an oversimplification since, as we have shown here, pyochelin will induce its own biosynthetic genes. This positive feedback mechanism allows a rapid adaptation of the bacterial cells to iron-depleted environments. Interestingly, yersiniabactin induces its own biosynthetic genes in $Y$. enterocolitica and $Y$. pestis (Pelludat et al., 1998; Bearden et al., 1997) and pyoverdin up-regulates its own expression in P. aeruginosa (Stintzi et al., 1997). Thus, positive autoregulation may be a general phenomenon in siderophore biosynthetic pathways. In the case of pyochelin biosynthesis, positive autoregulation comes to a halt when the system has provided the cells with sufficient intracellular iron, which switches off the synthesis of pyochelin and of the FptA receptor. 
Does pyochelin exert its inducing effect in the cytoplasm or from without, e.g. by interacting with the FptA receptor? In the second case, the inducing signal could be generated at the cell surface or in the periplasm and then transmitted to PchR via an unidentified signal transduction pathway, akin to that of the ferric citrate regulatory system in E. coli (Braun, 1997). There is some circumstantial evidence from the data of Heinrichs \& Poole (1996) that activation of $f p t A$ expression by pyochelin may involve the functional FptA receptor itself. However, in that study no attempt was made to dissociate the uptake functions from the inferred regulatory functions of FptA. At any rate, the present data do not allow us to decide whether pyochelin activates the PchR protein directly, by physical interaction, or indirectly, via a receptor-dependent signal transduction pathway.

\section{Conclusion}

As a rule, the end product of a biosynthetic pathway represses or feedback-inhibits the key enzyme(s) of the pathway in bacteria. Certain extracellular metabolites disobey this textbook rule as they stimulate their own synthesis. Autoinduction is a well-known phenomenon in cell-cell communication mediated by $N$-acyl homoserine lactones, which for this reason are sometimes called autoinducers (Fuqua \& Greenberg, 1998). However, autoinduction also characterizes the synthesis of the siderophores pyochelin (this study), pyoverdin (Stintzi et al., 1997) and yersiniabactin (Pelludat et al., 1998). It would not be surprising if autoinduction of extracellular metabolites turned out to be a widespread phenomenon in bacterial adaptation.

\section{ACKNOWLEDGEMENTS}

We thank Zöhre Ucurum for competent technical assistance, Martina Kotthaus and Arnaud Seematter for help with chemical identification of metabolites and SmithKline Beecham for a generous gift of carbenicillin. This work was supported by the Swiss National Foundation for Scientific Research (project 31-45896.95) and by the European biotechnology project IMPACT II (BIO4-CT96-0027).

\section{REFERENCES}

Ankenbauer, R. G. \& Cox, C. D. (1988). Isolation and characterization of Pseudomonas aeruginosa mutants requiring salicylic acid for pyochelin biosynthesis. J Bacteriol 170, 5364-5367.

Ankenbauer, R. G. \& Quan, H. N. (1994). FptA, the Fe(III)pyochelin receptor of Pseudomonas aeruginosa: a phenolate siderophore receptor homologous to hydroxamate siderophore receptors. J Bacteriol 176, 307-319.

Barton, H. A., Johnson, Z., Cox, C. D., Vasil, A. I. \& Vasil, M. L. (1996). Ferric uptake regulator mutants of Pseudomonas aeruginosa with distinct alterations in the iron-dependent repression of exotoxin A and siderophores in aerobic and microaerobic environments. Mol Microbiol 21, 1001-1017.

Bearden, S. W., Fetherston, J. D. \& Perry, R. D. (1997). Genetic organization of the yersiniabactin biosynthetic region and con- struction of avirulent mutants in Yersinia pestis. Infect Immun $\mathbf{6 5}$, 1659-1668.

Braun, V. (1997). Surface signaling: novel transcription initiation mechanism starting from the cell surface. Arch Microbiol 167, 325-331.

Britigan, B. E., Rasmussen, G. T. \& Cox, C. D. (1997). Augmentation of oxidant injury to human pulmonary epithelial cells by the Pseudomonas aeruginosa siderophore pyochelin. Infect Immun 65, 1071-1076.

Calderwood, S. B. \& Mekalanos, J. J. (1987). Iron regulation of Shiga-like toxin expression in Escherichia coli is mediated by the fur locus. J Bacteriol 169, 4759-4764.

Carmi, R., Carmeli, S., Levy, E. \& Gough, F. J. (1994). (+)-(S)Dihydro-aeruginoic acid, an inhibitor of Septoria tritici and other phytopathogenic fungi and bacteria, produced by Pseudomonas fluorescens. J Nat Prod 57, 1200-1205.

Cox, C. D. (1980). Iron uptake with ferripyochelin and ferric citrate by Pseudomonas aeruginosa. J Bacteriol 142, 581-587.

Cox, C. D. (1982). Effect of pyochelin on the virulence of Pseudomonas aeruginosa. Infect Immun 36, 17-23.

Cox, C. D. \& Adams, P. (1985). Siderophore activity of pyoverdin in Pseudomonas aeruginosa. Infect Immun 48, 130-138.

Cox, C. D. \& Graham, R. (1979). Isolation of an iron-binding compound from Pseudomonas aeruginosa. J Bacteriol 137, 357-364.

Coyne, M. J., Jr \& Goldberg, J. B. (1995). Cloning and characterization of the gene $(r f c)$ encoding $\mathrm{O}$-antigen polymerase of Pseudomonas aeruginosa PAO1. Gene 167, 81-86.

Crosa, J. H. (1997). Signal transduction and transcriptional and posttranscriptional control of iron-regulated genes in bacteria. Microbiol Mol Biol Rev 61, 319-336.

Cunliffe, H. E., Merriman, T. R. \& Lamont, I. L. (1995). Cloning and characterization of $p v d S$, a gene required for pyoverdine synthesis in Pseudomonas aeruginosa: PvdS is probably an alternative sigma factor. J Bacteriol 177, 2744-2750.

Del Sal, G., Manfioletti, G. \& Schneider, C. (1988). A one-tube plasmid DNA mini-preparation suitable for sequencing. Nucleic Acids Res 16, 9878.

Farinha, M. A. \& Kropinski, A. M. (1990). High efficiency electroporation of Pseudomonas aeruginosa using frozen cell suspensions. FEMS Microbiol Lett 58, 221-225.

Fuqua, C. \& Greenberg, E. P. (1998). Self perception in bacteria: quorum sensing with acylated homoserine lactones. Curr Opin Microbiol 1, 183-189.

Gamper, M., Ganter, B., Polito, M. R. \& Haas, D. (1992). RNA processing modulates the expression of the $\operatorname{arcDABC}$ operon in Pseudomonas aeruginosa. J Mol Biol 226, 943-957.

Gehring, A. M., Bradley, K. A. \& Walsh, C. T. (1997). Enterobactin biosynthesis in Escherichia coli: isochorismate lyase (EntB) is a bifunctional enzyme that is phosphopantetheinylated by EntD and then acylated by EntE using ATP and 2,3-dihydroxybenzoate. Biochemistry 36, 8495-8503.

Gehring, A. M., Mori, I. \& Walsh, C. T. (1998). Reconstitution and characterization of the Escherichia coli enterobactin synthetase from EntB, EntE and EntF. Biochemistry 37, 2648-2659.

Guilvout, I., Mercereau-Puijalon, O., Bonnefoy, S., Pugsley, A. P. \& Carniel, E. (1993). High-Molecular-Weight Protein 2 of Yersinia enterocolitica is homologous to AngR of Vibrio anguillarum and belongs to a family of proteins involved in nonribosomal peptide synthesis. J Bacteriol 175, 5488-5504.

Haese, A., Schubert, M., Herrmann, M. \& Zocher, R. (1993). 
Molecular characterization of the enniatin synthetase gene encoding a multifunctional enzyme catalysing $N$-methyldepsipeptide formation in Fusarium scirpi. Mol Microbiol 7, 905-914.

Heinrichs, D. E. \& Poole, K. (1993). Cloning and sequence analysis of a gene ( $p c h R$ ) encoding an AraC family activator of pyochelin and ferripyochelin receptor synthesis in Pseudomonas aeruginosa. $J$ Bacteriol 175, 5882-5889.

Heinrichs, D. E. \& Poole, K. (1996). PchR, a regulator of ferripyochelin receptor gene $(f p t A)$ expression in Pseudomonas aeruginosa, functions both as an activator and as a repressor. J Bacteriol 178, 2586-2592.

Jendrossek, D., Steinbuechel, A. \& Schlegel, H. G. (1988). Alcohol dehydrogenase gene from Alcaligenes eutrophus: subcloning, heterologous expression in Escherichia coli, sequencing and location of $\operatorname{Tn} 5$ insertions. J Bacteriol 170, 5248-5256.

Konz, D., Klens, A., Schörgendorfer, K. \& Marahiel, M. A. (1997). The bacitracin biosynthesis operon of Bacillus licheniformis ATCC 10716: molecular characterization of three multi-modular peptide synthetases. Chem Biol 4, 927-937.

Ku, J., Mirmira, R. G., Liu, L. \& Santi, D. V. (1997). Expression of a functional non-ribosomal peptide synthetase module in Escherichia coli by coexpression with a phosphopantetheinyl transferase. Chem Biol 4, 203-207.

Leoni, L., Ciervo, A., Orsi, N. \& Visca, P. (1996). Iron-regulated transcription of the pvdA gene in Pseudomonas aeruginosa: effect of Fur and PvdS on promoter activity. J Bacteriol 178, 2299-2313.

Lobocka, M., Hennig, J., Wild, J. \& Klopotowski, T. (1994). Organization and expression of the Escherichia coli $\mathrm{K}-12$ dad operon encoding the smaller subunit of D-amino acid dehydrogenase and the catabolic alanine racemase. J Bacteriol 176, $1500-1510$

Lopez, P. J. \& Dreyfus, M. (1996). The lacZ mRNA can be stabilized by the T7 late mRNA leader in E. coli. Biochimie 78, $408-415$.

McMorran, B. J., Merriman, M. E., Rombel, I. T. \& Lamont, I. L. (1996). Characterization of the $p v d E$ gene which is required for pyoverdine synthesis in Pseudomonas aeruginosa. Gene 176, 55-59.

Marahiel, M. A. (1997). Protein templates for the biosynthesis of peptide antibiotics. Chem Biol 4, 561-567.

Martell, A. E. \& Smith, R. M. (1977). Other organic ligands. In Critical Stability Constants, vol. 3, pp. 181-201. Edited by A. E. Martell \& R. M. Smith. New York: Plenum.

Meyer, J. M. (1992). Exogenous siderophore-mediated iron uptake in Pseudomonas aeruginosa: possible involvement of porin OprF in iron translocation. J Gen Microbiol 138, 951-958.

Meyer, J. M. \& Abdallah, M. A. (1978). The fluorescent pigment of Pseudomonas aeruginosa: biosynthesis, purification and physicochemical properties. J Gen Microbiol 107, 130-138.

Meyer, J. M., Neely, A., Stintzi, A., Georges, C. \& Holder, I. A. (1996). Pyoverdin is essential for virulence of Pseudomonas aeruginosa. Infect Immun 64, 518-523.

Miyazaki, H., Kato, H., Nakazawa, T. \& Tsuda, M. (1995). A positive regulatory gene, $p v d S$, for expression of pyoverdin biosynthetic genes in Pseudomonas aeruginosa PAO. Mol Gen Genet 248, 17-24.

Ochsner, U. A., Vasil, A. I. \& Vasil, M. L. (1995). Role of the ferric uptake regulator of Pseudomonas aeruginosa in the regulation of siderophores and exotoxin A expression: purification and activity on iron-regulated promoters. J Bacteriol 177, 7194-7201.

Pelludat, C., Rakin, A., Jacobi, C. A., Schubert, S. \& Heesemann, J. (1998). The yersiniabactin biosynthetic gene cluster of Yersinia enterocolitica: organization and siderophore-dependent regulation. J Bacteriol 180, 538-546.

Poole, K., Neshat, S., Krebes, K. \& Heinrichs, D. E. (1993). Cloning and nucleotide sequence analysis of the ferripyoverdine receptor gene $f p v A$ of Pseudomonas aeruginosa. J Bacteriol 175, $4597-4604$.

Prentki, P. \& Krisch, H. M. (1984). In vitro insertional mutagenesis with a selectable DNA fragment. Gene 29, 303-313.

Ratledge, C., Macham, L. P., Brown, K. A. \& Marshall, B. J. (1974). Iron transport in Mycobacterium smegmatis : a restricted role for salicylic acid in the extracellular environment. Biochim Biophys Acta 372, 39-51.

Rinehart, K. L., Staley, A. L., Wilson, S. R., Ankenbauer, R. G. \& Cox, C. D. (1995). Stereochemical assignment of the pyochelins. J Org Chem 60, 2786-2791.

Rusnak, F., Faraci, W. S. \& Walsh, C. T. (1989). Subcloning, expression and purification of the enterobactin biosynthetic enzyme 2,3-dihydroxybenzoate-AMP ligase: demonstration of enzyme-bound (2,3-dihydroxybenzoyl)adenylate product. Biochemistry 28, 6827-6835.

Sambrook, J., Fritsch, E. F. \& Maniatis, T. (1989). Molecular Cloning: a Laboratory Manual, 2nd edn. Cold Spring Harbor, NY: Cold Spring Harbor Laboratory.

Schneider, A. \& Marahiel, M. A. (1998). Genetic evidence for a role of thioesterase domains, integrated in or associated with peptide synthetases, in non-ribosomal peptide biosynthesis in Bacillus subtilis. Arch Microbiol 169, 404-410.

Serino, L., Reimmann, C., Baur, H., Beyeler, M., Visca, P. \& Haas, D. (1995). Structural genes for salicylate biosynthesis from chorismate in Pseudomonas aeruginosa. Mol Gen Genet 249, 217-228.

Serino, L., Reimmann, C., Visca, P., Beyeler, M., Della Chiesa, V. \& Haas, D. (1997). Biosynthesis of pyochelin and dihydroaeruginoic acid requires the iron-regulated pchDCBA operon in Pseudomonas aeruginosa. J Bacteriol 179, 248-257.

Simon, R., Priefer, U. \& Puhler, A. (1983). A broad host range mobilization system for in vitro genetic engineering: transposon mutagenesis in Gram negative bacteria. Bio-technology 1, 784-790.

Stachelhaus, T. \& Marahiel, M. A. (1995). Modular structure of peptide synthetases revealed by dissection of the multifunctional enzyme GrsA. J Biol Chem 270, 6163-6169.

Stanisich, V. A. \& Holloway, B. W. (1972). A mutant sex factor of Pseudomonas aeruginosa. Genet Res 19, 91-108.

Stintzi, A., Meyer, J.-M. \& Poole, K. (1997). The pvc gene cluster of Pseudomonas aeruginosa: role in the synthesis of the pyoverdin chromophore and regulation by the exotoxin A regulator PtxR. VI International Congress on Pseudomonas: Molecular Biology and Biotechnology. Madrid, Spain 1997.

Tomalsky, M. E., Actis, L. A. \& Crosa, J. H. (1993). A single amino acid change in AngR, a protein encoded by pJM1-like virulence plasmids, results in hyperproduction of anguibactin. Infect Immun 61, 3228-3233.

Visca, P., Ciervo, A., Sanfilippo, V. \& Orsi, N. (1993). Ironregulated salicylate synthesis by Pseudomonas spp. J Gen Microbiol 139, 1995-2001.

Voisard, C., Keel, C., Haas, D. \& Défago, G. (1989). Cyanide production by Pseudomonas fluorescens helps suppress black root rot of tobacco under gnotobiotic conditions. EMBO J 8, 351-358.

Voisard, C., Bull, C. T., Keel, C., Laville, J., Maurhofer, M., Schnider, U., Défago, G. \& Haas, D. (1994). Biocontrol of root 
diseases by Pseudomonas fluorescens CHA0: current concepts and experimental approaches. In Molecular Ecology of Rhizosphere Microorganisms, pp. 67-89. Edited by F. O. Gara, D. N. Dowling \& B. Boesten. Weinheim: VCH.

Watson, A. A., Alm, R. A. \& Mattick, J. S. (1996). Construction of improved vectors for protein production in Pseudomonas aeruginosa. Gene 172, 163-164.

Ye, R. W., Haas, D., Ka, J. O., Krishnapillai, V., Zimmermann, A.,
Baird, C. \& Tiedje, J. M. (1995). Anaerobic activation of the entire denitrification pathway in Pseudomonas aeruginosa requires Anr, an analog of Fnr. J Bacteriol 177, 3606-3609.

Zocher, R. \& Keller, U. (1997). Thiol template peptide synthesis systems in bacteria and fungi. Adv Microbiol Physiol 38, 85-131.

Received 25 June 1998; revised 30 July 1998; accepted 3 August 1998. 